\title{
Model Pembelajaran Numbered Head Together Berbantuan Media Peta Konsep Terhadap Kompetensi Pengetahuan IPA
}

\author{
Ni Putu Noviarini1 ${ }^{*}$, I Ketut Ardana², I Komang Ngurah Wiyasa3 \\ 123 Jurusan Pendidikan Dasar, Universitas Pendidikan Ganesha, Singaraja, Indonesia
}

\begin{abstract}
Abstrak
Penelitian ini bertujuan untuk menganalisis pengaruh model pembelajaran Numbered Head Together berbantuan media peta konsep terhadap kompetensi pengetahuan IPA siswa kelas IV. Jenis penelitian ini adalah Quasi eksperimen dengan menggunakan Nonequivalent Control Group Design. Populasi yang digunakan yaitu siswa kelas IV yang berjumlah 252 siswa. Penelitian ini menggunakan 2 kelompok sampel yang ditentukan melalui teknik Random Sampling dan telah melewati uji kesetaraan. Kelompok eksperimen dalam penelitian ini berjumlah 39 siswa sedangkan kelompok kontrol dalam penelitian berjumlah 38 siswa. Dalam proses pengumpulan data, metode tes dipilih sebagai instrumen dengan jenis tes objektif pilihan ganda biasa. Data post test yang diperoleh dianalisis menggunakan uji-t dengan rumus polled varians. Rata-rata nilai post test kompetensi pengetahuan IPA kelompok eksperimen yaitu 82,46 dan kelompok kontrol yaitu 76,26. Berdasarkan hasil analisis dengan uji t, diperoleh harga thitung $=3,668>t_{\text {tabel }}=1,992$ dengan taraf signifikansi $5 \%$ serta $\mathrm{dk}=75$ sehingga $\mathrm{H}_{\mathrm{o}}$ ditolak yang berarti adanya perbedaan yang signifikan antara kedua kelompok sampel. Maka disimpulkan bahwa model pembelajaran Numbered Head Together berbantuan media peta konsep memiliki pengaruh yang signifikan terhadap kompetensi pengetahuan IPA siswa kelas IV. Maka dari itu, penelitian ini membuktikan bahwa penerapan model pembelajaran Numbered Head Together berbantuan media peta konsep baik diterapkan dalam kegiatan belajar IPA dan dapat menjadikan kegiatan belajar mengajar menarik dan terarah sehingga berpengaruh terhadap kompetensi pengetahuan IPA siswa.
\end{abstract}

Kata Kunci:

NHT, peta konsep, IPA

\begin{abstract}
This study aims to determined the effect of the Numbered Head Together learning model assisted by the concept map media on the science knowledge competency grade IV Elementary School. This research type used Quasi experiment by Nonequivalent Control Group Design. The population used was all students of class IV Elementary School VIII Mengwi Badung, totaling 252 students. This study uses two sample groups determined through cluster random sampling techniques and has passed the equality test. This study experimental group was class IV which 39 students, while the control group in this study was class with a total of 38 students. In the data collection process, method test chosen as an instrument with the usual multiple choice objective test type. The post test data obtained were analyzed using ttest with polled variance formula. The average score of science competency post test in the experimental group is 82,46 and the control group is 76,26. Based on analysis results used $t$ test, the $t_{\text {count }}=3,668>t_{\text {table }}=1,992$ with a significance level of $5 \%$ and $\mathrm{dk}=75$ so that $\mathrm{H}_{0}$ is rejected, which means that there are significant differences between the two sample groups. Thus, it was concluded that Numbered Head Together learning model assisted by the concept map media has significant influence on the science knowledge competence of Grade IV.
\end{abstract}

Keywords:

NHT, concept maps, science

\footnotetext{
* Corresponding author. 


\section{PENDAHULUAN}

Pendidikan ialah bidang berperan penting bagi bangsa karena pendidikan dianggap sebagai suatu usaha untuk mencerdaskan kehidupan manusia dalam mempersiapkan generasi penerus bangsa yang berkualitas, memiliki keahlian, dan keterampilan. Di Indonesia pendidikan dibagi menjadi beberapa jenjang salah satunya adalah jenjang sekolah dasar (Asih, 2017). Pendidikan di SD merupakan hal yang sangat penting sebagai dasar bagi pendidikan selanjutnya (Putra, 2019). Maka dari itu, proses belajar mengajar yang diberikan di sekolah dasar harus dilaksanakan dengan baik agar terbentuk konsep dasar siswa yang kuat. Kesadaran tentang arti pentingnya pendidikan mendorong berbagai pihak untuk melakukan berbagai upaya agar perkembangan dunia pendidikan semakin maju, seperti dengan pengembangan kurikulum, peningkatan kompetensi guru, serta peningkatan sarana dan prasarana lainnya (Sari, 2017).

Upaya yang dilaksanakan pemerintah untuk meningkatkan mutu pendidikan ialah dengan pengembangan kurikulum (Dewi, 2019). Kurikulum ialah suatu dokumen penting yang harus dimiliki sekolah dan dijadikan dasar atau pedoman untuk mengarahkan pembelajar dalam mencapai tujuan pembelajaran. Kurikulum yang diberlakukan di Indonesia sekarang ialah Kurikulum 2013. Pelaksanaan kegiatan dalam proses belajar mengajar K13 diarahkan pada kompetensi berbasis sikap, keterampilan, dan pengetahuan yang berorientasi pada pendekatan saintifik yang dikemas dalam suatu tema (Padmadewi, 2017). Pada tema yang dibelajarkan terdapat beberapa muatan materi pelajaran, salah satunya yaitu IPA. Ilmu Pengetahuan Alam (IPA) merupakan salah satu muatan materi yang diberikan di SD. Muatan materi IPA sangat penting diberikan bagi siswa SD, karena melalui muatan materi IPA siswa diajarkan untuk mengenal Alam (Dewi, 2020). IPA ialah kumpulan ilmu pengetahuan membahas peristiwa-pristiwa alam disusun sistematis berdasarkan hasil pengamatan dan percobaan (Samatowa, 2018). Pembelajaran IPA di Sekolah dasar mempelajari tentang alam meliputi dari fakta-fakta, prinsipprinsip, konsep-konsep, serta proses dari suatu penemuan (Yanti, 2017).

Didasarkan atas hasil wawancara bersama guru wali kelas IV SD Gugus VIII Mengwi, menyatakan kompetensi pengetahuan IPA yang dimiliki oleh siswa di Gugus VIII Mengwi Badung belum optimal karena masih banyak siswa memperoleh nilai yang belum memenuhi kriteria ketuntasan minimal. Adapun beberapa masalah lain yang terjadi di sekolah dasar yaitu dalam kegiatan pembelajaran, siswa sulit memahami muatan materi IPA. Hal itu disebabkan karena muatan materi IPA dianggap sebagai pelajaran yang sulit dan menjadi beban bagi siswa, selain itu guru masih menerapkan pembelajaran konvensional yang didominasi dengan kegiatan ceramah, hal ini menyebabkan siswa kurang tertarik terhadap pelajaran IPA (ParamitaA., 2019). Pada saat pembelajaran berlangsung masih terlihat adanya siswa yang ribut dan tidak memperhatikan guru saat mengajar sehingga suasana kelas menjadi kurang kondusif (Dewi, 2020). Dalam proses pembelajaran siswa kurang aktif dan antusias pada kegiatan pembelajaran, sedangkan dalam kurikulum 2013 siswa dituntut untuk aktif selama proses pembelajaran berlangsung. Oleh karena itu, guru harus mampu mengemas dan merancang suatu kegiatan belajar dengan menggunakan model pembelajaran yang inovatif dan bervariasi sehingga peserta didik tertarik dan merasa senang dalam mengikuti proses pembelajaran (Atiyah, 2019). Selain itu pembelajaran yang terjadi di kelas lebih menekankan siswa pada kegiatan mengingat, menghafal, dan media pembelajaran yang hanya bersumber pada buku ajar, sehingga tidak menekankan pada siswa untuk memahami apa yang mereka pelajari. Dalam hal ini perlu diterapkan media pembelajaran yang menarik dan inovatif yang dapat membantu siswa untuk lebih memahami materi yang dipelajari dan meningkatkan kompetensi pengetahuan siswa (Muliandari, 2019).

Berdasarkan permasalahan maka perlu adanya perubahan cara mengajar agar dapat merangsang siswa lebih berperan aktif dalam proses pembelajaran, sehingga dalam kegiatan belajarnya siswa tidak hanya bergantung pada guru yang akan membuat siswa cenderung pasif dalam mengikuti proses pembelajaran (Adnyani, 2020). Maka dari itu, diterapkanlah model pembelajaran kooperatif tipe Numbered Head Together (NHT). Model pembelajaran kooperatif tipe Numbered Head Together dipilih karena cocok diterapkan pada proses pembelajaran karena dapat melibatkan semua siswa secara aktif bukan hanya satu dua orang saja (Atiyah, 2019). Menurut Kurnia (2019) model pembelajaran Numbered Head Together tepat digunakan karena memberikan peluang kepada siswa untuk membangun pengetahuannya sendiri dan sharing menggunakan konsep-konsep yang telah dimiliki untuk memecahkan masalah secara kelompok. Selain itu, Penggunaan model ini bertujuan untuk memberikan kesempatan kepada siswa untuk saling berbagi ide-ide dan mempertimbangkan jawaban yang paling tepat. Model pembelajaran Numbered Head Together adalah bagian dari model pembelajaran kooperatif struktural, yang menekankan pada struktur-struktur khusus yang dirancang untuk mempengaruhi pola interaksi siswa (Sudarwanto, 2018). Model pembelajaran ini memilik ciri khas dimana guru hanya menunjuk seorang siswa untuk mewakili kelompoknya tanpa memberitahu terlebih dahulu siapa yang 
akan mewakili kelompoknya tersebut. Sehingga cara ini menjamin keterlibatan total semua siswa. Cara ini upaya yang sangat baik untuk meningkatkan tanggung jawab individual dalam diskusi kelompok (Sugiyadnya, 2019). Spenser Kagen merupakan pengembang model pembelajaran Numbered Head Together yang ditujukan agar memudahkan siswa menganalisis isi pelajaran serta memeriksa pemahaman siswa terhadap suatu konsep (Trianto, 2015). Selain itu Paramita (2016) menyatakan Numbered Head Together dapat membuat semua siswa menjadi siap, sungguh-sungguh dalam diskusi, dan tidak ada yang paling mendominasi saat pelajaran berlangsung sebab siswa dipanggil secara acak, dan saat berdiskusi siswa dalam kelompoknya akan menyatukan pendapat dan saling membantu sesama teman dalam memahami pelajaran ataupun saat proses diskusi. Model pembelajaran Numbered Head Together menggunakan empat tahapan (sintaks) yakni pemberian nomor, pengajuan pertanyaan, berdiskusi bersama, dan menjawab. Tujuan model ini ialah untuk memberian peluang pada siswa untuk berbagi pengetahuan dan memilih jawaban terbaik (Huda, 2017). Adapun manfaat model pembelajaran Numbered Head Together menurut Priansa (2017) yaitu percaya diri siswa lebih meningkat, kemampuan berkomunikasi siswa lebih meningkat, toleransi lebih berkembang, pemahaman mengenai materi semakin mendalam dan meningkatkan hasil siswa dalam belajar.

Setiap model memiliki kelebihan dalam penerapannya, begitu juga dengan Numbered Head Together. Menurut Berlin \& Kurniasih (2015) kelebihan Numbered Head Together yatu lebih meningkatnya prestasi siswa, pemahaman siswa lebih mendalam, rasa tanggung jawab siswa lebih tinggi, rasa ingin tahu menjadi lebih berkembang, percaya diri siswa lebih meningkat, lebih berkembangnya rasa kerja sama, lebih termotivasinya siswa dalam menguasai materi, terciptanya suasana riang dalam belajar, perbedaan antara yang siswa pintar dan tidak pintar berkurang.

Suatu model pembelajaran tidak akan lengkap jika tidak disertai dengan media pembelajaran. Segala yang dipergunakan menyampaikan materi dari pendidik pada peserta didik disebut dengan media pembelajaran (Priansa, 2017). Untuk memudahkan pendidik menyalurkan materi pelajaran kepada peserta didik, maka media yang baik diterapkan ialah peta konsep. Muzaini (2019) menyatakan peta konsep merupakan gambaran grafis konkret yang menghubungkan suatu gagasan dengan gagasan lain yang sejenis atau memiliki hubungan. Menurut Putra (2019) peta konsep merupakan suatu konsep ilustrasi grafis yang dihubungkan ke konsep lain agar membuat struktur berpikir peserta didik menjadi lebih sederhana. Dalam peta konsep siswa dilatih untuk mengidentifikasi konsep yang berhubungan dengan suatu topik dan menyajikannya ke dalam suatu pola atau bagan (Wirandari, 2020). Peta konsep terdiri dari 3 macam jenis peta konsep yaitu cycle concept map, events chain map, dan network tree map .

Model pembelajaran Numbered Head Together berbantuan media peta konsep cocok dipergunakan pada proses belajar mengajar di sekolah dasar karena model pembelajaran Numbered Head Together mengutamakan kerja sama kelompok dengan penomoran kepala berstuktur yang selanjutnya diberikan pertanyaan untuk didiskusikan dalam kelompok. Saat berdiskusi semua anggota kelompok harus menyatukan pendapatnya dan memahami jawaban dari hasil diskusi kelompok. Dalam proses diskusi ini diterapkan media peta konsep untuk membantu menyelesaikan masalah. Menurut Dewi (2017) Model pembelajaran Numbered Head Together dipadukan dengan peta konsep menjadi kombinasi yang cocok digunakan untuk belajar bersama dan saling berbagi gagasan antar siswa, kemudian siswa menuliskan materi/gagasan yang diperoleh siswa dengan membuat peta konsep, sehingga struktur berpikir peserta didik jadi lebih sederhana dan membuatnya lebih memahami dan mengerti suatu konsep. Jadi model pembelajaran Numbered Head Together dengan bantuan media peta konsep ini dapat meningkatkan kompetensi pengetahuan IPA.

Pernyataan tersebut didukung oleh hasil penelitian yang relevan dari Purwati (2019) menyatakan adanya pengaruh model pembelajaran Numbered Head Together berbantuan gambar terhadap kompetensi pengetahuan IPA. Adapun penelitian dari Laksmi (2017) yang menyatakan adanya pengaruh model pembelajaran Numbered Head Together berbantuan media visual tiga dimensi terhadap kompetensi pengetahuan IPA sebagai pendukung penelitian ini. Selain itu penelitian ini didukung pula oleh Sari (2017) yang menyatakan model pembelajaran kooperatif tipe Numbered Head Together berbantuan question cards berpengaruh terhadap kompetensi pengetahuan IPA. Serta diperkuat oleh penelitian dari Puspawati (2017) menyatakan model pembelajaran kooperatif tipe Team Assisted Individualization berbantuan peta konsep berpengaruh terhadap kompetensi pengetahuan IPA. Dan penelitian ini dudukung oleh penelitian dari Kurnia (2019) yang menyatakan model pembelajaran Number Head Together (NHT) Berbantuan media puzzle memiliki pengaruh terhadap hasil belajar. Dan sesuai pula penelitian dari Nilayanti (2017) yang menyatakan adanya pengaruh model pembelajaran kooperatif tipe Numbered Head Together berbantuan media konkret terhadap kompetensi pengetahuan IPA siswa kelas IV. Hasil dari penelitian tersebut relevan dengan penelitian ini karena menggunakan variabel yang sama dengan penelitian ini sehingga berdasarkan penelitian tersebut dapat dinyatakan 
bahwa model pembelajaran Numbered Head Together dan media peta konsep memiliki pengaruh terhadap kompetensi pengetahuan IPA.

Berdasarkan pemaparan masalah, maka diterapkan model pembelajaran Numbered Head Together dengan peta konsep pada kompetensi pengetahuan IPA kelas IV di Gugus VIII Mengwi Badung 2019/2020. Tujuan dari penelitian untuk menganalisis pengaruh model pembelajaran Numbered Head Together dengan peta terhadap kompetensi pengetahuan IPA siswa kelas IV SD Gugus VIII Mengwi Badung Tahun Ajaran 2019/2020.

\section{METODE PENELITIAN}

Jenis Penelitian menggunakan metode ekperimen yang merupakan bagian dari metode kuantitatif. Metode eksperimen ialah metode penelitian yang berfungsi untuk menentukan pengaruh dari suatu treatment. Penelitian ini menggunakan desain Quasi Experimental Design. Rancangan quasi eksperimen digunakan dalam bidang pendidikan subjek yang diteliti adalah orang, sehingga peneliti tidak dapat mengontrol penuh. Adapun bentuk desain yang dipergunakan ialah Nonequivalent-Control-Group-Design sebagai berikut:

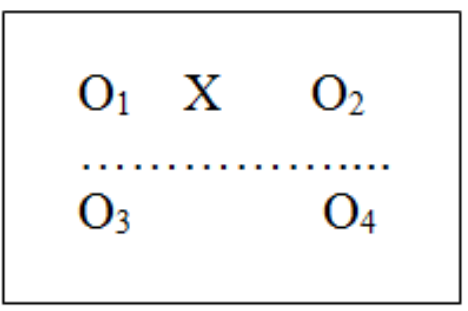

Gambar 1. Desain Penelitian Nonequivalent Control Group Design

(Sumber : Sugiyono, 2017:79)

Pada desain ini, melibatkan dua kelompok sampel yaitu kelompok eksperimen dan kelompok kontrol (Wulandari, 2018). Kedua kelompok yang terlibat diberikan pre test untuk mengukur pengetahuan siswa sebelum diberikan perlakuan. Perlakuan yang diberikan yaitu dengan menerapkan model pembelajaran Numbered Head Together berbantuan media peta konsep pada kelompok eksperimen dan pembelajaran konvensional kepada kelompok kontrol. Kemudian sesudah diberikan perlakuan, lalu dilaksanakan post tes kepada kedua kelompok sampel untuk mengetahui kompetensi pengetahuan IPA siswa setelah diberikan perlakuan.

Pada pelaksanaannya penelitian meliputi beberapa tahap yakni tahapan persiapan eksperimen, tahapan pelaksanaan ekperimen, serta tahapan akhir eksperimen. Adapun populasi pada penelitian ini adalah seluruh kelas IV SD Gugus VIII Mengwi yang terdiri dari 8 kelas dan berjumlah 252 siswa merupakan popolasi yang dipergunakan. Sedangkan sampel atau bagian dari populasi penelitian dipilih melalui teknik Random Sampling melalui pengundian kelas, sehingga setiap kelas memiliki peluang yang sama untuk menjadi sampel penelitian. Cara penggundian dilaksanakan dengan menuliskan kelas IV di seluruh sekolah dasar Gugus VIII Mengwi pada kertas, kemudian kertas digulung. Semua gulungan kertas kemudian dimasukan pada botol dan diundi agar mendapat 2 kelas sampel. Nama kedua kelas hasil undian pada gulungan kertas tersebut merupakan sampel penelitian. Dalam pengundian ini 2 gulungan kertas yang keluar yaitu kelas IV SD Nomor 1 Mengwi sampel I dengan kelas IV ${ }_{B}$ SD Nomor 3 Mengwi sebagai sampel II.

Setelah diperoleh sampel penelitian, kemudian menentukan kesetaraan kelompok sampel dengan cara mengukur kemampuan awal siswa dengan melaksanakan pre test pada kedua kelompok sampel, lalu dilanjutkan dengan dilakukan uji kesetaraan. Uji kesetaraan dilakukan dengan menganalisis nilai pre test kedua kelompok sampel. Sebelum dilaksanakan uji kesetaraan menggunakan uji-t, kedua kelompok harus diuji normalitas sebaran data melalui uji chi kuadrat serta uji homogenitas varians melali uji Fisher. Apabila pengujian prasyarat dipenuhi, kemudian dapat dilakukan uji kesetaran mempergunakan uji-t.

Didasarkan atas analisis uji-t kedua kelompok sampel setara dengan hasil perhitungan memperoleh nilai $t_{\text {hitung }}=1,297$, selain itu berdasarkan taraf signifikansi $5 \%$ serta $\mathrm{dk}=75$ maka diperoleh $t_{\text {tebel }}=1$,992. Jadi $t_{\text {hitung }}<t_{\text {tabel }}$ sehingga terjadi penerimaan $H_{0}$ yang artinya kedua kelompok sampel setara. Setelah kedua kelompok sampel setara kemudian dilanjutkan mengundi untuk memilih kelompok kontrol serta kelompok eksperimen. Hasil undian menyatakan kelompok eksperimennya yakni kelas IV SD Nomor 1 Mengwi dan kelompok kontrol yakni kelas IV ${ }_{B}$ SD Nomor 3 Mengwi. 
Data yang digunakan dalam penelitian ialah nilai post test kompetensi pengetahuan IPA kedua kelompok. Dalam proses mengumpulkan data, metode yang dipergunakan ialah metode tes. Metode tes ialah metode yang digunakan dalam memperoleh data dalam bentuk tugas yang dikerjakan testee untuk mendapatkan suatu skor. Metode tes merupakan instrumen yang digunakan dalam menggumpulkan data penelitian yang bertujuan untuk mengukur kompetensi siswa dalam ranah pengetahuan. Instrumen atau alat ukur yang digunakan dalam penelitian ini adalah tes berupa tes objektif berbentuk pilihan ganda biasa yang terdiri dari 4 pilihan option (a,b,c,atau d). Tes pilihan ganda disusun sesuai dengan kisi-kisi soal yang disusun berdasarkan kompetensi dasar (KD) dan indikator yang sesuai dengan buku pedoman guru (buku tematik tema 6 cita-citaku) dan materi yang dipelajari serta berpedoman pada landasan kurikulum yang ada yakni kurikulum 2013. Butir soal yang dibuat untuk mengukur kompetensi pengetahuan IPA siswa terdiri dari 50 butir soal berbentuk pilihan ganda biasa.

Sebelum instrumen digunakan, terlebih dahulu dilaksanakan uji pakar, uji pakar dilakukan oleh dua orang pakar (dosen pembimbing dan guru kelas) guna mendapatkan kualitas tes yang baik. Kemudian instumen tes tersebut diuji kevalidan butir soalnya melalui beberapa pengujian instrumen. Pengujian instrumen tes dilaksanakan dengan mengujicobakan instrumen tes (butir soal) pada kelompok kelas yang lebih tinggi dari kelas sampel. Setelah diujicobakan, nilai hasil uji instrumen tersebut dianalisis kevalidan butir tes dengan beberapa pengujian instrumen yakni uji validitas, uji tingkat kesukaran, uji daya beda, dan uji reliabilitas. Didasarkan atas hasil uji instrumen dari 50 butir soal menghasilkan 34 butir soal yang valid yang dapat dipergunakan mengukur kemampuan kompetensi pengetahuan IPA siswa.

Teknik penskoring dalam penelitian ini dilakukan dengan mencocokan jawaban siswa dengan kunci jawaban. Adapun ketentuan dalam memberi skor yakni apabila siswa menjawab dengan benar butir tes mendapat skor $=1$ dan siswa menjawab dengan salah butir tes mendapatkan skor $=0$. Kemudian untuk memperoleh nilai akhir dilakukan membagi skor yang diperoleh siswa dibagi dengan skor maksimum dan dikalikan 100, maka diperoleh nilai akhir siswa dengan skala 100.

Penelitian ini menggunakan dua variabel yaitu bebas dan terikat (Laksmi, 2017). Titik fokus berupa konsep dalam penelitian disebut variabel. Variabel yang munculnya karena pengaruh atau dari terdapatnya variabel bebas disebut variabel terikat. Kompetensi pengetahuan IPA ialah variabel terikat penelitian. Sedangkan Variabel yang sengaja diteliti pengaruhnya pada variabel terikat disebut variabel bebas. Variabel bebas penelitian ini ialah model pembelajaran NHT berbantuan peta konsep. NHT dengan media peta konsep merupakan variabel bebas penelitian. NHT adalah cara mengajar yang mengutamakan kerja sama kelompok dengan pemberian nomor kepada setiap siswa lalu diberikan pertanyaan untuk didiskusikan antar kelompoknya. Dalam proses diskusi ini, digunakan bantuan media peta konsep untuk memahami materi. Peta konsep ialah gambaran konkret yang menghubungkan antar konsep.

Statistik inferensial merupakan teknik dan metode dipergunakan dalam menganalisis data sampel untuk membuat simpulan yang berlaku pada populasi, statistik inferensial yang dipergunakan yaitu statistis parametris yang kegunaannya menguji populasi dari sampel (Sugiyono, 2017). Untuk melakukan uji statisti parametrik diperlukan persyaratan yang meliputi data berdistribusi normal dan homogen. Untuk menentukan data sampel yang diperoleh normal dalam distribusinya ataupun tidak maka perlu dilaksanakan pengujian normalitasi sebaran data. Data sampel yang berdistribusi normal artinya data memiliki persebaran seimbang dan sempurna dari skor rata-rata. Pengujian ini dapat diuji dengan teknik Chi Kuadrat. Kriteria pengujiannya didasarkan taraf signifikasi $5 \%$, apabila $\chi_{\text {hitung }}^{2}<\chi_{\text {tabel }}^{2}$ artinya datanya berdistribusi normal. Pengujian prayarat yang kedua yang harus dipenuhi ialah uji homegenitas varians. Uji homogenitas varians dilaksanakan untuk memastikan perbedaan dalam kelompoklah yang menjadi sebab terjadinya perbedaan pada pengujian hipotesis dan bukan karena perbedaan antar kelompok. Maka dari itu, uji $\mathrm{F}$ dilakukan dengan ketentuan yaitu apabila $\mathrm{F}_{\text {hitung }} \leq \mathrm{F}_{\text {tabel }}$ maka data homogen.

Jika uji prasayarat terpenuhi maka pengujian hipotesis mempergunakan statistik parametrik dapat dilaksanakan. Hipotesis nol yang diuji adalah tidak terdapat pengaruh kompetensi pengetahuan IPA pada kelompok siswa yang diajarkan mempergunakan model pembelajaran Numbered Head Together dengan bantuan media peta konsep dan kelompok siswa yang diajarkan mempergunakan pembelajaran konvensional pada siswa kelas IV SD Gugus VIII Mengwi Badung tahun ajaran 2019/2020. Analisis statistik yang dipergunakan untuk pengujian hipotesis ialah uji beda mean (uji t) mempergunakan rumus polled varians karena jumlah sampel penelitian ini $\mathrm{n} 1 \neq \mathrm{n} 1$ dan varians homogen. Dengan kriteria yaitu apabila $t_{\text {hitung }} \leq t_{\text {tabel }}$ maka $H_{0}$ diterima ataupun penolakan $H_{a}$, sedangkan apabila $t_{\text {hitung }}>t_{\text {tabel }}$ maka terjadi penolakan $\mathrm{H}_{0}$ dengan kata lain yakni penerimaan $\mathrm{H}_{\mathrm{a}}$ dengan didasarkan atas $\mathrm{dk}=(\mathrm{n} 1+\mathrm{n} 2-2)$ dan taraf signifikansi $5 \%$. 


\section{ANALISIS DAN PEMBAHASAN}

Pelaksanaan proses pembelajaran selama penelitian secara umum berlangsung sesuai dengan rencana pembelajaran yang telah disusun. Data penelitian meliputi dua kelompok data yakni, (1) kompetensi pengetahuan IPA kelas IV yang dibelajarkan mempergunakan model pembelajaran Numbered Head Together berbantuan media peta konsep pada kelompok eksperimen, serta (2) kompetensi pengetahuan IPA yang diajarkan mempergunakan pembelajaran konvensional pada kelompok kontrol. Siswa kelas IV SD Nomor 1 Mengwi ialah kelompok eksperimen dalam penelitian ini yang berjumlah 39 orang. Setelah diberikan perlakuan (treatment) sebanyak 6 kali dengan mempergunakan model Numbered Head Together dengan peta konsep. Sedangkan Kelas IV $_{B}$ SD Nomor 3 Mengwi merupakan kelompok kontrol penelitian dengan jumlah 38 siswa. Kelompok ini dialajarkan dengan pembelajaran konvensional, dan setelah 6 kali pertemuan. Untuk mendapatkan data kompetensi pengetahuan IPA maka diberikanlah post test pada kedua kelompok sampel penelitian.

Berdasarkan hasil perhitungan data nilai post test kompetensi pengetahuan IPA, nilai rata-rata kelompok eksperimen ialah 82,46 lebih tinggi dibandingkan dengan mean kelompok kontrol yakni 76,26. Didasarkan atas kriteria nilai PAP maka nilai rerata kelompok eksperimen masuk kedalam katagori baik sedangkan nilai rata-rata kelompok kontrol masuk dalam katagori cukup.

Dalam menganalisis menggunakan uji t, mengharuskan data memenuhi uji prasyarat. Pengujian prasyarat yang harus dilaksanakan yakni uji normalitas dan uji homogenitas (Pratiwi, 2017). Pengujian normalitas sebaran data dilaksanakan dengan mempergunakan data nilai post test kompotensi pengetahuan IPA kelas IV kedua kelompok. Perlunya dilakukan pengujian ini agar dapat ditentukan normal atau tidaknya distribusi sebaran data. Pada tabel berikut disajikan rekapitulasi hasil uji normalitas kelompok eksperimen dan kelompok kontrol penelitian.

Tabel 1. Hasil Rekapitulasi Uji Normalitas Kelompok Eksperimen dan Kelompok Kontrol

\begin{tabular}{cllcc}
\hline No & \multicolumn{1}{c}{ Sampel } & $\chi_{\text {hitung }}^{2}$ & $\chi_{\text {tabel }}^{2}$ & Distribusi Data \\
\hline 1 & Kelompok Eksperimen & 8,83 & 11,07 & Normal \\
2 & Kelompok Kontrol & 9,99 & 11,07 & Normal \\
\hline
\end{tabular}

Berdasarkan taraf signifikansi 5\% serta derajat kebebasan $=(6-1)=5$ didapat $\mathrm{X}^{2}$ tabel $=11,07$. Nilai $\mathrm{X}^{2}$ hitung kelompok eksperimen $=8,83$, sedangkan $\mathrm{X}^{2}$ hitung kelompok kontrol = 9,99 karena kedua kelompok $\mathrm{X}^{2}$ hitung $<\mathrm{X}^{2}$ tabel sehingga terjadi penerimaan $\mathrm{H}_{\mathrm{o}}$ yang artinya sebaran data post test kompetensi pengetahuan IPA kelompok eksperimen dan kelompok kontrol normal dalam distribusi datanya.

Pengujian prasyarat kedua yang harus dipenuhi ialah uji homogenitas varians. Pengujian dilaksanakan untuk memenuhi pengujian prasyarat dan membuktikan bahwa perbedaan dalam kelompoklah yang menjadi sebab perbedaan dalam uji hipotesis dan bukan karena perbedaan antar kelompok. Pengujian homogenitas mempergunakan uji Fisher yang dihitung dengan membagi varian terbesar dengan varian terkecil (Febbriana, 2019). Berikut dijabarkan hasil rekapitulasi uji homogenitas varian kelompok eksperimen dan kelompok control penelitian.

Tabel 2. Hasil Rekapitulasi Uji Homogenitas Kelompok Eksperimen dan Kelompok Kontrol

\begin{tabular}{lccccc}
\hline \multicolumn{1}{c}{ Sampel } & $\begin{array}{c}\text { Standar Deviasi } \\
(\boldsymbol{S D})\end{array}$ & $\begin{array}{c}\text { Varians } \\
\left(\boldsymbol{S}^{2}\right)\end{array}$ & $\boldsymbol{F}_{\text {hitung }}$ & $\boldsymbol{F}_{\text {tabel }}$ & Keterangan \\
\hline Kelompok Eksperimen & 7,62 & $\begin{array}{c}58,10 \\
56,69\end{array}$ & 1,02 & 1,73 & Homogen \\
Kelompok control & 7,53 & & & \\
\hline
\end{tabular}

Dari hasil pengujian didapatkan $F_{\text {hitung }}=1,02$, lalu bandingkan dengan nilai $F_{\text {tabel. Berdasarkan }}$ tarafisignifikansi 5\%, dan dk pembilang = 38 dan penyebut $=37$ diperoleh $\mathrm{F}_{\text {tabel }}=1,73$. Sehingga diperoleh $\mathrm{F}_{\text {hitung }}<\mathrm{F}_{\text {tabel, }}$ artinya nilai post test kompetensi pengetahuan IPA kedua kelompok homogen.

Apabila telah terpenuhi uji prasyarat maka dapat dilaksanakan pengujian hipotesis. Hipotesis yang diujikan pada penelitian ialah $\mathrm{H}_{0}$ yang berbunyi tidak terdapat perbedaan yang signifikan kompetensi pengetahuan IPA antara kelompok siswa yang dibelajarkan melalui model pembelajaran Numbered Head Together berbantuan media peta konsep dan kelompok siswa yang dibelajarkan melalui pembelajaran konvensional pada siswa kelas IV SD Gugus VIII Mengwi Badung tahun ajaran 2019/2020. Pengujian hipotesis menggunakan statistik parametrik dengan teknik uji-t menggunakan rumus polled varians, 
karena sudah terpenuhinya uji prasyarat. Pada tabel berikut disajikan rekapitulasi uji hipotesis penelitian kelompok eksperimen dan kelompok kontrol dengan menggunakan uji t.

Tabel 3. Hasil Rekapitulasi Uji-t Post test kompetensi pengetahuan IPA

\begin{tabular}{|c|c|c|c|c|c|c|c|c|}
\hline No & Sampel & $\mathbf{N}$ & Dk & $\bar{x}$ & $S^{2}$ & $t_{\text {hitung }}$ & $t_{\text {tabel }}$ & Keterangan \\
\hline 1 & Kelompok Eksperimen & 39 & & 82,46 & 58,10 & & & \\
\hline 2 & Kelompok Kontrol & 38 & 75 & 76,26 & 56,69 & 3,668 & 1,992 & $\begin{array}{l}\text { Chitung > label } \\
\mathrm{H}_{0} \text { ditolak }\end{array}$ \\
\hline
\end{tabular}

Didasarkan atas analisis uji-t, nilai $t_{\text {hitung }}=3,668$, sedangkan nilai $t_{\text {tabel }}$ pada taraf signifikansi $5 \%$ dengan $\mathrm{dk}=(39+38-2)=75$ didapatkan $t_{\text {tabel }}=1$,992. Jadi $t_{\text {hitung }}>t_{\text {tabel }}$ maka terjadi penolakan $\mathrm{H}_{0}$. Sehingga terdapat perbedaan kompetensi pengetahuan IPA yang dibelajarkan melalui model pembelajaran Numbered Head Together berbantuan media peta konsep dengan yang dibelajarkan melalui pembelajaran konvensional pada siswa kelas IV SD Gugus VIII Mengwi Badung tahun ajaran 2019/2020.

Keberhasilan dari penelitian ini disebabkan oleh media dan model yang dipergunakan pada kelompok eksperimen. Kelompok eksperimen dibelajarkan dengan penerapan Numbered Head Together sebagai model pembelajaran dengan bantuan media peta konsep. Dalam penerapan model pembelajaran Numbered Heads Together dikelas eksperimen terlihat bahwa seluruh anggota kelompok aktif dalam berdiskusi dan bertukar pikiran dalam memecahkan masalah yang diberikan oleh guru, tingkat penguasaan materi siswa juga mengalami peningkatakan, karena ketika siswa mengalami kesulitan, teman satu teman satu kelompoknya akan membantu siswa tersebut agar seluruh anggota kelompok menjadi siap jika nantinya dipanggil oleh guru secara acak, hal ini sesuai dengan pendapat Nugroho (2019) menjelaskan bahwa Numbered Head Together merupakan model pembelajaran di mana setiap siswa di beri nomor dan di buat kelompok yang kemudian secara acak guru memanggil nomor siswa. Selain itu, pembelajaran Numbered Head Together merupakan salah satu tipe pembelajaran kooperatif yang menekankan pada struktur khusus yang dirancang untuk mempengaruhi pola interaksi siswa dan memiliki tujuan untuk meningkatkan penguasan akademik.

Kelebihan dari model pembelajaran NHT yakni prestasi belajar lebih meningkat, rasa ingin tahu siswa lebih berkembang, lebih mendalamnya pemahaman siswa, rasa tanggungjawab siswa lebih tinggi, membuat suasana pembelajaran kelompok yang mengembirakan, serta perbedaan antara siswa pintar dan tidak pintar menjadi lebih berkurang. Setelah menemukan konsep dan gagasan yang tepat mengenai suatu materi, siswa lalu menuangkan gagasan yang mereka dapatkan tersebut ke dalam peta konsep, sehingga materi yang dipelajari siswa lebih mudah dimengerti dan dipahami dengan dibuatkannya peta konsep. Peta konsep merupakan gambaran konkret yang menghubungkan suatu gagasan dengan gagasan lain yang sejenis atau memiliki hubungan (Trianto, 2015). Jadi Model Pembelajaran NHT dengan bantuan media peta konsep adalah kombinasi yang cocok diterapkan untuk belajar bersama dengan menuliskan materi atau konsep yang diperoleh peserta didik dengan membuat peta konsep, sehingga struktur berpikir peserta didik jadi lebih sederhana dan peserta didik akan lebih mudah memahami pelajaran.

Berdasarkan hasil temuan selama penelitian, dapat dinyatakan bahwa pembelajaran dengan model Numbered Head Together membuat siswa lebih tertantang dalam belajar sehingga berpengaruh terhadap kemampuan kognitif siswa, karena siswa tidak akan pernah tahu kapan guru akan memanggil nomor yang ada pada kepala mereka. Hal inilah yang memacu siswa harus lebih giat belajar agar mampu menjawab pertanyaan yang diberikan oleh gurunya. Melalui model pembelajaran Numbered Head Together ini siswa dapat leluasa dalam mengemukakan pendapat dan belajar menghargai pendapat orang lain dengan tetap mengacu pada materi dan tujuan pembelajaran sehingga dapat meningkatkan hasil belajar siswa. Menghargai pendapat orang lain sangat diperlukan didalam melakukan diskusi. Berdasarkan penelitian yang dilakukan pada kelompok eksperimen, banyak siswa dalam kelompok yang mau mendengarkan apa yang disampaikan oleh kelompok lain walaupun jawaban kelompok tersebut belum terbukti benar. Sehingga proses diskusi berjalan dengan baik. Jadi, model pembelajaran kooperatif tipe Numbered Head Together ini berpotensi dan cocok diterapkan serta dikembangkan lagi untuk meningkatkan kompetensi pengetahuan siswa.

Pengembangan model pembelajaran ini dapat dilakukan dengan disertai penerapan metodemetode dan media pembelajaran yang inovatif dan kreatif yang disesuaikan dengan kondisi kurikulum dan materi yang diajarkan. Sehingga dengan adanya pengembangan model pembelajaran ini dapat mengubah pandangan masyarakat sosial dari yang biasanya mengetahui kegiatan pembelajaran secara konvensional berupa ceramah dan mendengarkan penjelasan guru, sekarang sudah berubah menjadi pembelajaran yang kooperatif dan inovatif dengan diterapkan model pembelajaran Numbered Head 
Together ini. Sehingga dengan adanya temuan ini, dapat mengubah pandangan masyarakat bahwa sumber belajar bukan hanya dari guru, melainkan dapat diperoleh dari teman sebaya, lingkungan, maupun dengan cara mencari atau membangun pengetahuannya sendiri.

Adapun implikasi yang diperoleh setelah penerapan model pembelajaran Numbered Head Together adalah model ini merupakan model yang tepat dan cocok diterapkan dalam proses pembelajaran karena dapat memberi pengaruh terhadap kompetensi pengetahuan peserta didik. Penelitian ini membuktikan bahwa model pembelajaran Numbered Head Together berbantuan peta konsep baik dan tepat diterapkan dalam kegiatan pembelajaran dan dapat menjadikan kegiatan belajar mengajar menarik dan terarah sehingga berpengaruh terhadap peningkatan kompetensi pengetahuan IPA siswa. Sedangkan dalam implikasi praktisnya model pembelajaran Numbered Head Together berbantuan peta konsep dapat dipergunakan sebagai sebagai tambahan informasi untuk guru dalam menentukan model pembelajaran yang bervariasi yang dapat dijadikan sebagai pilihan untuk menentukan strategi pembelajaran, dikarenakan model Numbered Head Together terbukti dapat meningkatkan minat serta pemahaman dan bertujuan untuk menjadikan siswa lebih kreatif dan inovatif sesuai dengan kebijakan dan tujuan dari kurikulum 2013.

Didasarkan atas uji analisis dan pemaparan teori, kompetensi pengetahuan IPA kelompok eksperimen lebih unggul dibandingkan kelompok kontrol. Pernyataan itu didukung penelitian yang relevan dari Nilayanti (2017) yang menyatakan adanya pengaruh model pembelajaran kooperatif tipe Numbered Head Together berbantuan media konkret terhadap kompetensi pengetahuan IPA siswa kelas IV SD Gugus Kompyang Sujana Denpasar. Pernyataan tersebut didukung pula oleh hasil penelitian dari Purwati (2019) menyatakan adanya pengaruh model pembelajaran Numbered Head Together dengan bantuan gambar terhadap kompetensi pengetahuan IPA. Selain itu penelitian ini didukung oleh Sari (2017) yang menyatakan model pembelajaran kooperatif tipe Numbered Head Together berbantuan question cards berpengaruh terhadap kompetensi pengetahuan IPA. Pernyataan tersebut sejalan dengan hasil penelitian Muliandari (2019) yang menyatakan adanya pengaruh model pembelajaran Numbered Head Together terhadap kompetensi pengetahuan siswa. Sesuai juga dengan pernyataan Anggara (2017) yang menyatakan adanya pengaruh dari penerapan media peta konsep terhadap kompetensi pengetahuan siswa. Serta sesuai dengan penelitian dari Sari (2017) yang menyatakan model pembelajaran kooperatif tipe Numbered Head Together berpengaruh terhadap kompetensi pengetahuan IPA. Relevansi penelitian ini dengan penelitian sebelumnya ialah sama-sama meneliti tentang Kompetensi pengetahuan IPA dengan menerapkan model pembelajaran Numbered Head Together berbantuan media peta konsep.

Berdasarkan pemaparan tersebut, dapat disimpulkan bahwa model pembelajaran Numbered Head Together berbantuan media peta konsep berpengaruh terhadap kompetensi pengetahuan IPA siswa kelas IV SD Gugus VIII Mengwi Badung Tahun Ajaran 2019/2020.

\section{KESIMPULAN}

Didasarkan atas analisis data, disimpulkan model pembelajaran Numbered Head Together berbantuan media peta konsep berpengaruh terhadap kompetensi pengetahuan IPA siswa kelas IV SD Gugus VIII Mengwi Badung Tahun Ajaran 2019/2020. Adapun beberapa rekomendasi yang disampaikan kepada beberapa pihak yang terkait dengan hasil penelitian yaitu kepada guru diharapkan untuk mempergunakan model pembelajaran dan mempergunakan sumber belajar dan media yang lebih bervariasi, seperti Numbered Head Together dan media peta konsep untuk mengembangkan kemampuan dan pemahamannya. Kepada kepala sekolah disarankan agar menciptakan suasana belajar yang dapat membuat para pendidik menerapkan berbagai model pembelajaran untuk meningkatkan mutu dan kualitas peserta didik agar jadi lebih baik. Kepada siswa disarankan dengan dilaksanakannya berbagai model pembelajaran khususnya Numbered Head Together dan peta konsep bisa membuat siswa jadi lebih aktif, bertanggung jawab, membentuk interaksi yang positif antar siswa dan dapat meningkatan minat belajar agar diperoleh prestasi yang gemilang. Serta direkomendasikan juga kepada peneliti lain untuk mempergunakan hasil penelitian ini untuk pedoman melaksanakan penelitian selanjutnya yang memiliki persamaan variabel dengan penelitian ini. Sehingga model pembelajaran ini dapat berkembang dan memberikan pengaruh yang lebih baik terdapat kompetensi pengetahuan siswa. 


\section{DAFTAR PUSTAKA}

Adnyani, I. A. N., Widya, \& Wiarta, I. W. (2020). Pengaruh Model Pembelajaran ( VAK ) Berbasis Whole Brain Teaching Terhadap Kompetensi Pengetahuan IPA. Mimbar PGSD, 8(1), 80-88.

Anggara, I Md Citra; Ardana, I Kt; Darsana, I. W. (2017). Pengaruh Model Pembelajaran Kooperatif tipe TPS Berbantuan Peta Konsep Terhadap Penguasaan Kompetensi Pengetahuan IPA Siswa Kelas IV. Mimbar PGSD, 5(2), 272-280. https://doi.org/10.23887/jjpgsd.v5i2.10754

Asih, N. P., Suka, Negara, I. G. A. O., \& Sujana, I. W. (2017). Pengaruh Model Pembelajaran NHT Berbantuan Media Konkret Terhadap Kompetensi Pengetahuan IPS Siswa Kelas IV SD. Mimbar PGSD, 5(2).

Atiyah, U., Fita, M., Untari, A., \& Tsalatsa, A. N. (2019). Keefektifan Model Pembelajaran Numbered Head Together ( NHT ) Dengan Media Teka-Teki Silang Terhadap Hasil Belajar Tematik Siswa. International Journal of Elementari Education, 3(1), 46-52.

Berlin, S., \& Kurniasih, I. (2015). Ragam Pengembangan Model Pembelajaran Untuk Peningkatan Profesionalitas Guru (A. Jay (ed.); I). Kata Pena.

Dewi, A. D. Y. R., \& Kristiantari, M. G. R. (2020). Pengaruh Model Pembelajaran Auditory Intellectually Repetition Berbantuan Multimedia Terhadap Kompetensi Pengetahuan IPA. Mimbar Ilmu, 25(1), 75-86.

Dewi, N. L. R. D., Sujana, I. W., \& Kristiantari, M. R. (2017). Pengaruh Model pembelajaran Kooperatif Tipe Numbered Head Together Berbantuan Media Powerpoint Terhadap Kompetensi Pengetahuan IPS. Mimbar PGSD, 5(2).

Dewi, N. P. Y. K., Wiyasa, K. N., \& Ardana, I. K. (2018). Pengaruh Model Pembelajaran Snowball Throwing Berbantuan Medialingkungan Terhadap Kompetensi Pengetahuan IPA. Jurnal Pedagogi Dan Pembelajaran, 1(1). https://doi.org/10.23887/jp2.v1i1.19322

Febbriana, I. R. A., Ardana, I. K., \& Agustika, G. N. S. (2019). Pengaruh Model Pembelajaran Word Square Berbasis Outdoor Study Terhadap Kompetensi Pengetahuan IPA Siswa. Mimbar PGSD, 7(2), 149156.

Huda, M. (2017). Model-Model Pengajaran dan Pembelajaran (VI). Pustaka Pelajar.

Kurnia, V. T., Damayani, A. T., \& Kiswoyo, K. (2019). Keefektifan Model Pembelajaran Number Head Together (NHT) Berbantu Media Puzzle Terhadap Hasil Belajar. Jurnal Ilmiah Sekolah Dasar, 3(2), 192. https://doi.org/10.23887/jisd.v3i2.17772

Laksmi, I. G. A. A. W., Suadnyana, I. N., \& Wiyasa, I. K. N. (2017). Model Pembelajaran Numbered Head Together Berbantuan Media Visual Tiga Dimensi Terhadap Kompetensi Pengetahuan IPA. Mimbar $P G S D, 5(2)$.

Muliandari, P. T. V. (2019). Pengaruh Model Pembelajaran Kooperatif Tipe NHT ( Numbered Head Together ) Terhadap Hasil Belajar Matematika. International Journal of Elementari Education, 3(2), $132-140$.

Muzaini. (2019). Strategi Peta Konsep Tingkatkan keaktifan dan Hasil Belajar Siswa (A. Dwianto (ed.)). CV. Beta aksara.

Nilayanti, M. M., Putra, I. ketut A., \& Suadnyana, I. N. (2017). Pengaruh Model Pemebelajaran Kooperatif Tipe Numbered Head Together Berbantuan Media Konkret Terhadap Kompetensi Pengetahuan IPA Siswa Kelas IV SD Gugus Kompyang Sujana Denpasar Utara. Mimbar PGSD, 5(2).

Nugroho, A. F., \& Wardani, K. W. (2019). Perbedaan Model Pembelajaran Kooperatif Tipe Numbered Heads Together dan Think Pair Share Ditinjau dari Hasil Belajar Siswa. Jurnal Ilmiah Sekolah Dasar, 
$3(4), 497-506$.

Padmadewi, N. N. (2017). Pengantar Micro Teaching. Rajawali Pers.

Paramita, N. P. I., Ardana, I. K., \& Putra, I. K. A. (2016). Pengaruh Model Pembelajaran Two Stay Two Stray Berbantuan Peta Konsep Terhadap Hasil Belajar IPS Siswa Kelas V SD Gugus I Kecamatan Gianyar Tahun 2015/2016. Jurnal Mimbar PGSD Universitas Pendidikan Ganesha, 4(1), 1-10. http://ejournal.undiksha.ac.id/index.php/JJPGSD/article/download/7052/4809

ParamitaA., N. L. P. A., Japa, I. G. N., \& Sudatha, I. G. W. (2019). Pengaruh Model Contextual Teaching and Learning Berbantuan Masalah Realistis Terhadap Keterampilan Berpikir Kritis IPA. Thinking Skills and Creativity Journal, 1(2), 56. https://doi.org/10.23887/tscj.v1i2.20499

Pratiwi, T. A., Wiarta, I. W., \& Sujana, I. W. (2017). Pengaruh Model Pembelajaran Cooperative TSTS Berbantuan Peta Konsep Terhadap Kompetensi Pengetahuan IPA Siswa Kelas V. Mimbar PGSD, $5(2)$.

Priansa, D. J. (2017). Pengembangan Strategi \& Model Pembelajaran (I). CV Pustaka Setia.

Purwati, N. L. P. D., Wibawa, I. M. C., \& Margunayasa, I. G. (2019). Pengaruh Numbered Head Together Berbantuan Gambar Terhadap Penguasaan Kompetensi Pengetahuan IPA. Jurnal Pedagogi Dan Pembelajaran, 2(3), 282. https://doi.org/10.23887/jp2.v2i3.19275

Puspawati, L. D., Darsana, I. W., \& Putra, M. (2017). Pengaruh Model Pembelajaran Kooperatif Tipe TAI Berbantuan Peta Konsep Terhadap Kompetensi Pengetahuan IPS Kelas V. Mimbar PGSD, 5(2).

Putra, I. D. G. D., Darsana, I. W., \& Putra, M. (2019). Pengaruh Model Pembelajaran Berbasis Masalah Berbantuan Peta Konsep Terhadap Kompetensi Pengetahuan IPS. Jurnal Ilmiah Sekolah Dasar, 3(3), 387. https://doi.org/10.23887/jisd.v3i3.19479

Samatowa, U. (2018). Pembelajaran IPA di Sekolah Dasar (B. Sarwiji (ed.); 4th ed.). indeks penerbit.

Sari, N. K. T. N., Suniasih, N. W., \& Wiarta, I. W. (2017). Pengaruh Model Pembelajaran Kooperatif Tipe NHT Berbantuan Question Cards Terhadap Kompetensi Pengetahuan IPA. Mimbar PGSD, 5(2). https://doi.org/10.23887/jjpgsd.v5i2.10660

Sudarwanto, W., Relmasira, S. C., \& Juneau, J. L. (2018). Penerapan Model Pembelajaran Kooperatif Tipe NHT Berbantuan Media Simulasi Gambar Untuk Meningkatkan Hasil Belajar Siswa Kelas 4 SD Semester 1 Tahun 2017/2018.1-10.

Sugiyadnya, I. K. J., Wiarta, I. W., \& Putra, I. K. A. (2019). Pengaruh Model Pembelajaran Kooperatif Learning Tipe NHT terhadap Pengetahuan Matematika. International Journal Of Elementari Education, 3(4), 413-422.

Sugiyono. (2017). Statistika Untuk Penelitian (28th ed.). Cv. ALFABETA.

Trianto. (2015). Mendesain Model Pembelajaran Inovatif, Progresif, dan Kontektual : Konsep, Landasan, dan Implementasi pada Kurikulum 2013. Prenadamedia Group.

Wirandari, N., Mirah, G. A., \& Kristiantari, M. G. R. (2020). Pengaruh Model Pembelajaran Cooperative Integrated Reading And Composition Berbantuan Peta Konsep Terhadap Kemampuan Membaca Pemahaman. Jurnal Pedagogi Dan Pembelajaran, 3(1), 55-63.

Wulandari, P., Abadi, I. B. G., \& Suniasih, N. W. (2018). Pengaruh Model Pembelajaran Think Pair Share Berbasis Penilaian Portofolio Terhadap Kompetensi Pengetahuan IPA Siswa Kelas IV SS Negeri Gugus Kapten Kompyang Sujana Denpasar Barat Tahun 2017/2018. Mimbar PGSD, 6(3), 161-168. 
https://doi.org/10.23887/jjpgsd.v6i3.15772

Yanti, N. L. G. M. V., Suadnyana, I. N., \& Manuaba, I. B. S. (2017). Pengaruh Model Pembelajaran NHT Berbasis Concept Mapping Terhadap Kompetensi Pengetahuan IPA Siswa Kelas IV SD. Mimbar PGSD, 5(2). https://doi.org/10.23887/jjpgsd.v5i2.10752 